\title{
Review of Giorgio Agamben (2021). Where Are We Now? The Epidemic as Politics
}

\author{
Trans. V. Dani. Lanham, MA: Rowman \& Littlefield. 104 pp. ISBN \\ 9781538157602 (Paperback)
}

\author{
John Reader ${ }^{1,2}$
}

Accepted: 28 June 2021 / Published online: 8 July 2021

(C) The Author(s), under exclusive licence to Springer Nature Switzerland AG 2021

Keywords Covid-19 · Pandemic · Lockdown - Social distancing · Biopolitics · Postdigital $\cdot$ Humanity $\cdot$ Barbarism $\cdot$ Bare life $\cdot$ Human interaction

\section{The End of Politics as Civic Participation}

On 26 June 2021, Matt Hancock, Secretary of State for Health and Social Care in the UK government and the minister probably most closely associated with the response to the pandemic, resigns having been caught on camera failing to observe his own social distancing rules. An ironic illustration of Agamben's telling summary of the pandemic times: 'We are facing a paradox: the end of all social relations and political activity is presented as the exemplary form of civic participation.' (Agamben 2021: 60). Hancock contravenes this new approach to civic participation by making the mistake of combining a social relationship with political activity and becomes another victim (albeit a painless one) of the pandemic.

Agamben has written one of the most critical academic responses to the events of the last 18 months and raised concerns that some might find exaggerated. The context is his own nation of Italy, and the book consists of a series of short articles and interviews produced up until November 2020, so in advance of the roll out of the various vaccines across the world. Even so, many questions and uncertainties remain about where we are and what the future now holds. Whether or not one fully agrees with his interpretation, there is much here that demands attention.

In common with Naomi Klein's (2008) shock doctrine thesis, Agamben works on the principle that those in power will not allow a good crisis to go to waste, but rather will take the opportunity to press forward on practices and policies that match their political agenda. A new paradigm of governance is emerging, one that attempts to

John Reader

drjohnreader@hotmail.co.uk

1 William Temple Foundation, Rochdale, UK

2 Institute of Education, University of Worcester, Worcester, UK 
reverse the declining power of national leaders: 'The dominant powers of today have decided to pitilessly abandon the paradigm of bourgeois democracy - with its rights, its parliaments, and its constitutions - and replace it with new apparatuses whose contours we can barely glimpse.' (Agamben 2021: 8) This is based on 'the state of exception', the suspension of normal activities on the grounds that we face an unprecedented challenge that governments can only respond to by abandoning that earlier paradigm.

For Agamben, this has disturbing echoes of Germany in 1933, although this time what is happening is the introduction of a sanitation of terror and a religion of health. 'Biosecurity' is the term he uses to describe this. Once a threat to our health is presented, then we are apparently prepared to accept limitations on our freedoms that would have been unthinkable even a few months beforehand. Not even two world wars or indeed many authoritarian regimes would have persuaded the general populace to undergo such sacrifices.

Central to this process is the deployment of digital technology, working in harmony with the new structure of relationships known as 'social distancing'. Human relationships will have to happen as much as possible without physical presence, and this depends upon the mediation of the digital. This was already underway but has been accelerated by the response to the pandemic in which the new paradigm is that of connection, or for some, disconnection. As this postdigital transformation (Jandrić et al. 2018) takes hold, almost by default, new forms of resistance will need to be developed, ones which will not revert to the old bourgeois patterns of governance.

\section{The Atmosphere of Fear; the Religion of Money}

As Agamben was writing during the early stages of the pandemic, it is easy to recognise the various restrictions to which he was referring, particularly the prohibitions of any form of social gathering and public events and indeed closure of places of entertainment. What is it that created the context in which so many of us were prepared to accept this? It was an atmosphere of fear. The first wave of panic in Italy shows that the society believes in nothing but 'bare life', illustrated by the fact that Italians are prepared to sacrifice almost everything, life conditions, social relationships, their work, and even friendships as well as religious and political commitments, when faced with the risk of getting sick. 'Bare life, and the fear of losing it, is not something that unites people; rather it blinds and separates them.' (Agamben 2021: 18).

The neighbour has been cancelled, and even the churches from whom one might have expected more of a protest have acquiesced in this. Life is reduced to a minimum, nothing more than existence stripped of all other aspects. Survival is all that counts when faced with the fear of the virus and living under this regime requires sacrificing freedoms for 'security reasons' and risks living in a perpetual state of fear and insecurity. The impact of this upon children has yet to be properly researched, but when one hears accounts of a grandchild on encountering her grandfather for the first time in many months, stretching out an arm to make sure he is kept at arm's 
length for fear of abandoning the social distancing that has become the accepted norm, one questions the damage to relationships that has been created and how long this may take to heal.

What has replaced the immediate physical presence of course is the operations of the digital which now mediate relationships of all kinds, not simply the personal and private, but also the professional and educational. Working from home is offered as the alternative to risking being in the real presence of one's colleagues or clients. Beyond this is the wider political issue of the impact of this upon public space and public discourse. If we can no longer meet in person or in groups to engage in open conversation, it becomes much easier for external powers to control and manipulate lone individuals deprived of the benefit of wider discussion and debate.

One might argue that this was then, the early stages of the pandemic, and that things will return to normal in due course, but Agamben is clear that this will not be the case. One reason will be that people will start to question their lifestyles and values as it becomes more evident that so many of the external trappings of our lives are unnecessary and simply feed consumption capitalism and the damage it creates. In the course of travelling around the globe with such speed and intensity, we have lost the ability to dwell (Agamben 2021: 21), seduced by the religion of money, and the possessions to which that gives us access. Our former way of life is brought into question, at least, that is the argument. Whether this will emerge in a permanent way is not so obvious once travel returns to pre-Covid-19 levels. Much has been made of the benefits of walking and spending time out in the open-for those able to do so- - but will this fade over time?

\section{Crossing the Threshold Between Humanity and Barbarism}

Agamben attributes much of the response to the pandemic to the dominance of biopolitics, where what is at stake is biological life as such: 'the new element is that health is becoming a juridical obligation that has to be fulfilled at all costs' (Agamben 2021: 29). What is surprising is that the two religions that seem to hold the West together-those being Christianity and Capitalism-have kept quiet in the face of the diminishing of relationships required by social distancing. This term itself betrays an ideological determination as one could just as easily talk about confinement-I remember commenting that it was like being under house arrest. Being denied the opportunity to meet with one's family and friends especially if they lived at a distance did indeed feel like a form of imprisonment. Even now coming out on the other side of this where one is allowed to travel and mix to some extent feels awkward and disconnected.

The normal bonds of human relationship have been broken and knowing that this can happen so easily and rapidly is itself disconcerting and disturbing. When and under what conditions might it happen again? What are the implications of this for 'community' or previous forms of communal activity? Agamben goes so far as to say that the threshold between humanity and barbarism has been crossed (34). Our neighbour is someone to be feared and avoided as they might be contagious and a threat to our own health and wellbeing. 
In part, this has happened because science is now allowed to be the driving force behind the political decisions — or so we are told - as it is the data that will determine what we are allowed to do and when. When our lives are reduced to data, is life any longer worth living as Stiegler (2013) pointed out? Renouncing the good to save or preserve the good is a false and contradictory principle; we forego freedom in order to protect it. It is the fear of illness and of course death that has determined this willingness to abandon social relationships, but is this any way to live our lives as so many other threats are always present even though this particular one might fade over time?

Agamben presses the case for science as the new religion and refers to the risks of handing ethical and political decisions over to those who pursue their own research at the expense of other considerations. He argues that like theologians, they defend different and often conflicting interpretations, and then attempt to control our lives on the basis of these (Agamben 2021: 45). Beyond this then are questions of truth and reliability, and the difficulties the layperson has in understanding and interpreting the statistics that are presented to us on a daily basis. How are we to know that the figures are correct, or to question the ways in which they are shaped?

We are passive consumers of the media reports just as we are of advertising, and yet any questioning of the statistics is deemed to be an act of civic irresponsibility. In particular, it is science in the form of medicine that is now the dominant factor. Agamben points out that medicine articulates its ideas through a Gnostic or Manichean lens. There is a malign god or principle - the virus - and a beneficent god or principle which is not health, but recovery with doctors as the cultic agents. As in every Gnostic faith, these two can just as easily collaborate or contaminate each other. The cultic practice which is essential to this religion is the mandatory social distancing and wearing of masks.

Yet other health threats suddenly slip beneath the radar to the point where health services are then overwhelmed by the backlog of procedures which themselves will lead to further deaths. The crisis becomes permanent although taking on other forms, so what further restrictions will be demanded in order to combat these threats to our health as bare life? Even with the virus we are now fighting further mutations and outbreaks despite the vaccination programmes. Will there ever be an end to this?

\section{Face Masks Against Public Life}

Such scenarios had been predicted even if not effectively anticipated, including the imposition of restrictions along the lines we have now encountered, but much of this has been suppressed as presumably too disturbing for the public to handle. Everything now is being presented as trying to get life back to normal as quickly as possible, by which is actually meant getting businesses back to making profits and people back to work either digitally or in person. But what about the other changes that have been brought in alongside commercial activity and that will continue to impact our social and personal wellbeing? 
The long-term impact of these is yet to play out, particularly for younger generations who have come to experience this great disruption as the norm. While substantial gatherings of people at sporting events appear to be back on the agenda, presumably because of the money involved and because they might have a positive impact upon public morale, other more personal gatherings are still under restrictions in ways that seem inconsistent. So there is an illusion of normality alongside continued constraints upon other forms of human social and political activity.

Agamben argues that it is the concept of citizenship that is subtly being redefined (Agamben 2021: 67) as citizens are reduced to their bare biological existences-or perhaps as mere generators of income for large organisations? It is after all the Big Tech companies who appear to have benefitted the most from the digitalization of so many aspects of our lives, including course of the health services themselves. These processes were already underway but have been accelerated as the result of the pandemic (Jandrić 2021) to the point where the general public is being forced into compliance on the basis that there will be no alternatives.

One final argument that Agamben presents as a threat to political action is the wearing of masks as disrupting access to our faces. Without this openness to each other that comes only through being able to see (and read) the expressions of our faces, there is a real diminishment of public life. 'A country that decides to renounce its face, to cover with masks the faces of its citizens everywhere is, then, a country that has purged itself of any political dimension.' (Agamben 2021: 87) This essential form of human interaction and communication once lost cannot be replaced or replicated by the digital as that requires a different discipline and dynamic of exchange, one that is inevitably more stilted and disjointed. Perhaps this is to overstate the case, but it highlights issues that have yet to receive adequate attention and consideration.

What happens when health replaces salvation, biological life replaces eternal life, and social distancing displaces community? These are theological as well as political questions, and Agamben has correctly brought them to our attention.

\section{References}

Agamben, G. (2021). Where are we now? The Epidemic as Politics. Trans. V Dani. Lanham, MA: Rowman \& Littlefield.

Jandrić, P. (2021). Biology, Information, Society. Postdigital Science and Education, 3(2), 261-265. https:// doi.org/10.1007/s42438-021-00220-0.

Jandrić, P., Knox, J., Besley, T., Ryberg, T., Suoranta, J., \& Hayes, S. (2018). Postdigital Science and Education. Educational Philosophy and Theory, 50(10), 893-899. https://doi.org/10.1080/ 00131857.2018.1454000.

Klein, N. (2008). The Shock Doctrine: The Rise of Disaster Capitalism. London: Penguin.

Stiegler, B. (2013). What Makes Life Worth Living: On Pharmacology. Trans. D. Ross. Cambridge: Polity. 